\title{
ANALISIS SISTEM INFORMASI MANAJEMEN BERBASIS KOMPUTER DALAM PROSES MENGAMBIL SEBUAH KEPUTUSAN
}

\author{
Muhammad Khairul Amri \\ Prodi Sistem Informasi, Fakultas Sains Dan Teknologi, UINSU \\ Email: $\underline{\text { mhdkhairulamri64@gmail.com }}$
}

\begin{abstract}
Abstrak
Di dalam organisasi banyak sekali manfaat suatu sistem informasi bila digunakan sebaik mungkin. Maka dari itu sangat diperlukan suatu sistem manajemen yang bagus(bermutu) untuk mencapai dan mendukung tujuan organisasi tersebut. Di dalam suatu perusahaan tidak bisa terlepas dari berbagai macam, jenis, sumber masalah di dalam sebuah organisasi. Berbagai macam perubahan sering kali muncul, sehingga perubahan itu sangat sering menjadi hambatan untuk seorang manajer di perusahaan itu. Oleh karena itu diperlukanlah suatu sistem yang sangat diperlukan untuk mendukung seorang manajer untuk mengatasi masalah-masalah tersebut.
\end{abstract}

\section{Kata kunci(keyword)}

Analisis Sistem Informasi, Keputusan (ketetapan), Organisasi, Faktor-faktor, Jenis-jenis

\section{PENDAHULUAN :}

Pada jaman sekarang ini sistem informasi menjadi suatu kebutuhan hidup di semua kalangan masyarakat seperti halnya sandang, pangan dan papan. Di dalam beberapa hal sebuah informasi telah mampu mengguncangkan dunia di berbagai bidang kehidupan masyarakat. Setelah perkembangan teknologi informasi yang demikian pesatnya, maka semakin banyaklah perusahaan di Indonesia menerapkan Sistem Informasi Manajemen (SIM). Karena mereka mulai menyadari bahwa SIM(Sistem Informasi Manajemen) sangat besar manfaatnya bagi peningkatan kinerja di sebuah organisasi.

terbatas. Saat itu, proses pengambilan keputusan yang dilakukan masih sangat sederhana. Sistem Informasi Manajemen berbasis komputer mengandung arti bahwa komputer memainkan peranan penting dalam sebuah sistem informasi manajemen.

\section{STUDI LITERATUR}

Studi literatur yang saya ambil dari beberapa informasi di buku,makalah,journal dan sebagainya yang membahas Sistem Informasi Manajemen dengan konsep Analisis Sistem Informasi Manajemen Berbasis 
Komputer Dalam Proses Pengambilan Keputusan.

\section{METODE PENELITIAN}

Artikel ini sifatnya yaitu sebuah penelitian kepustakaan (library research), hingga data yang saya ambil yaitu dari beberapa kajian teks dan buku yang sangat relavan dengan pokok atau rumusan masalah yang sesuai dengan pembahasan artikel ini.

Penyusunan artikel ini dapat dikatakan sebagai suatu usaha pengumpulan dan pengolahan data pembahasan ini.

\section{HASIL PEMBAHASAN}

\section{Sistem Informasi Manajemen (SIM)}

Winarno (2004: 6) menjelaskan bahwa "kerangka data adalah sekumpulan bagian yang bekerja sama, yang digunakan untuk mencatat informasi, mengukur informasi, dan menyajikan data kepada para pemimpin untuk menggunakan penilaian yang baik". McLeod dan Schell (2009: 12) dalam bukunya yang berjudul Sistem Informasi Manajemen mencirikan bahwa "kerangka data administrasi adalah kerangka kerja berbasis PC yang membuat data untuk klien yang memiliki persyaratan komparatif. Klien SIM biasanya merupakan substansi atau sub-unit otoritatif formal di bawah itu. Data yang diberikan oleh SIM menggambarkan organisasi atau salah satu kerangka prinsipnya sejauh apa yang telah terjadi sebelumnya, apa yang sedang terjadi, dan apa yang mungkin akan terjadi nanti ". Sementara itu, sebagaimana ditunjukkan oleh Fahmi (2010: 77) bahwa "Sistem Informasi Pelaksana (SIM) merupakan aparatur administrasi yang digunakan untuk membantu pengurus organisasi dalam menerima, menangani dan menangani organisasi secara tepat dan metodis bertekad membantu produksi pelaksanaan organisasi “.

Board Information System (MIS) adalah organisasi data yang dibutuhkan oleh para pionir untuk menyelesaikan kewajiban mereka (untuk melayani asosiasi), terutama untuk menentukan pilihan dalam mencapai tujuan otoritatif.

Strategi MIS untuk memberikan data kepada direktur yang memberdayakan mereka untuk merencanakan dan mengendalikan tugas. PC telah menambahkan beberapa pengukuran, seperti kecepatan, presisi, dan volume informasi yang diperluas, yang memungkinkan pemikiran lebih banyak pilihan dalam sebuah pilihan, yang dalam suatu asosiasi terdiri dari berbagai komponen, individu yang memiliki pekerjaan berbeda dalam asosiasi, latihan atau tugas yang seharusnya selesai, lingkungan kerja, wewenang kerja, dan hubungan korespondensi yang mengikat asosiasi. SIM adalah penggunaan kerangka data di dalam asosiasi untuk membantu data yang dibutuhkan oleh semua jajaran eksekutif. Faktor yang menekan SIM 
adalah pada kerangka kerja, bukan pada administrasi, melainkan agar SIM dapat diselesaikan dengan sukses dan produktif, harus diawasi sebaik mungkin. Kerangka data dalam tahapannya dapat digambarkan sebagai struktur piramida, dengan lapisan yang paling sedikit menutupi data untuk penanganan pertukaran, pemeriksaan status, dll. Tahap berikut menggabungkan sumber data untuk membantu pengaturan strategis dan dinamis untuk pengawasan dan tahap atas menggabungkan data sumber untuk membantu pengaturan dan pembuatan strategi oleh administrasi yang lebih tinggi.

\section{Penerapan teknologi dalam suatu organisasi}

Kemajuan zaman membuat inovasi yang begitu cepat, sehingga pekerjaan inovasi sangat penting dalam setiap aspek Kerangka Data Eksekutif. Mulai dari dunia persekolahan hingga terjun ke dunia bisnis, masing-masing dari mereka memanfaatkan bahan / peralatan modern untuk membantu setiap orang dalam latihan.

Dalam pergaulan yang membingungkan, setiap perkumpulan memiliki berbagai macam alat / inovasi karena hal tersebut dikarenakan setiap perkumpulan berhasil dibentuk dengan mengubah kontribusi menjadi hasil dan sebaliknya dengan berbagai kemajuan. Perrow (1986), menunjukkan bahwa ada dua unsur latihan kerja yang mempunyai arti penting bagi konstruksi dan latihan yang terjadi dalam suatu asosiasi, khususnya:

\section{(1.)Ragam usaha (ragam tugas)}

Artinya, menunjukkan banyak pengecualian (kasus khusus) dalam pekerjaan, dan banyak kejadian tiba-tiba dalam siklus kerja

(2.)Kesederhanaan pemeriksaan (analizability) merupakan tugas yang tidak sulit untuk diselidiki dan dapat memperjelas beberapa kemajuan yang jelas dan robotik sehingga cenderung diselesaikan dengan strategi yang berkepala dingin dan dapat diukur secara kuantitatif. Pemikiran kritis sederhana karena setiap perkembangan dalam proses dapat diukur dengan jelas dan mudah dikenali jika ada penyimpangan. Thomson dan Perry (2007). Mengumpulkan inovasi data menjadi 3 jenis, termasuk mengklarifikasi jenis koneksi yang terjadi dengan pelanggan. Tiga pengelompokan asosiasi tersebut meliputi:

\section{1.) Inovasi orang tengah (perantara inovasi)}

Digunakan untuk menghubungkan beberapa pelanggan di mana satu pelanggan dengan pelanggan lain tidak dapat dikaitkan secara bersamaan, misalnya, jika Anda harus bertemu langsung, itu terlalu mahal dan terlalu sulit untuk dipikirkan.

2.) Sejak beberapa waktu yang lalu menghubungkan inovasi

Dalam inovasi semacam ini, latihan asosiasi terdiri dari beberapa fase 
gerakan progresif. Selain itu, konsekuensi dari latihan tersebut menjadi masukan (kontribusi) untuk latihan yang akan segera diselesaikan.

\section{3.) Inovasi terkonsentrasi (inovasi intensif)}

At Innovation Concentrated adalah kumpulan dari beberapa jenis layanan khusus, yang semuanya bergabung untuk melayani pelanggan. Inovasi ini pada umumnya diterapkan pada gerakan yang benar-benar berbahaya, sehingga mengganggu pelanggan yang mulai berubah. Sejak kemunculannya 50 tahun (50 tahun) sebelumnya, PC sering digunakan untuk perangkat penyusun informasi. Dengan memanfaatkan standar 1P0 (Information Interaction Yield), klien atau klien mengantisipasi bahwa komputer harus memiliki opsi untuk memberikan hasil tertentu dari berbagai jenis info yang diberikan.

Dahulu bentuk prosesnya hanya terbayas ada hal-hal semacam kalkulasi kuantitatif belaka, dalam perkembangannya sekarang ini sebuah komputer sudah berfungsi sebagai alatbantu untuk aktivitas keberlangsungan hidup manusia, Seperti: proses belajar, proses motivasi prosesperdagangan, dan lain-lainnya. Komputer menerima instruksi dari manusia (brainware) untuk melakukansejumlah pemrosesan data yang hasilnya untuk di presentasikan keoada yang bersangkutan.

\section{Analisis Sistem Informasi Manajemen (berbasis komputer)}

Dalam siklus menentukan pilihan. Bagian dari kerangka data administrasi berbasis PC dalam menentukan pilihan tentang nilai data yang diidentifikasi dengan pilihan soliter. Dimana bantuan kerangka kerja data eksekutif secara dinamis dalam sebuah asosiasi dapat digambarkan dengan tiga fase, siklus dinamis, secara khusus mendapatkan, merencanakan, dan memilih. Papan Dukungan Kerangka Data untuk sebagian besar mencakup data persiapan, PC dan non-PC. Pada tahap memahami hubungan dengan Kerangka Data Administrasi adalah siklus pemeriksaan yang mencakup pemeriksaan informasi baik dengan cara yang telah ditentukan atau menggunakan strategi yang luar biasa. Board Data Frameworks harus melakukan dua cara berbeda ini. Para eksekutif Data Frameworks sendiri perlu menyelidiki semua informasi dan mengajukan permohonan untuk diadili secara individu, keadaan saat ini jelas membutuhkan banyak pertimbangan. Kedua MIS dan asosiasi harus memberikan saluran korespondensi untuk masalah-masalah yang diketahui dengan jelas sehingga mereka dapat diteruskan ke tingkat yang lebih tinggi agar masalah-masalah ini ditangani oleh pertemuan. Pada tahap ini, penting juga untuk menandai beberapa prospek. Dukungan Kerangka Data dewan memerlukan basis informasi yang terkait dengan publik, pesaing, dan informasi orang dalam selain strategi untuk mengikuti dan menemukan masalah. Pada tahap perencanaan, hubungan dengan Kerangka Data Administrasi adalah untuk menentukan pilihan untuk persiapan tambahan tergantung pada informasi yang ada dan membuat dorongan (pemikiran) untuk menangani beberapa masalah. Dukungan SIM terdiri dari pemrograman faktual seperti halnya pemrograman tampilan lainnya. Ini mencakup beberapa metodologi 
terorganisir, mengendalikan model yang ada. Pada tahap penentuan, Kerangka Data Administrasi menjadi yang terbaik saat pencetus diperkenalkan dalam struktur untuk mendapatkan pilihan yang tepat.

Jika keputusan telah dibuat, bagian dari Kerangka Data Administrasi berubah menjadi kumpulan informasi untuk kritik. Dukungan Dewan Kerangka Data untuk tahap pilihan adalah untuk memilih berbagai jenis model pilihan, mengarahkan penyelidikan pengaruh (pemeriksaan pengaruh). Pilihan terdiri dari kumpulan data total, kapasitas pemulihan basis informasi, Pemrograman faktual dan berwawasan luas lainnya, seperti model penting yang menggabungkan pemograman pembuatan model pilihan. Ini menyiratkan bahwa ketika tidak ada keputusan atau pilihan, data menjadi tidak berguna. Pilihan dapat berubah dari pilihan iteratif dasar hingga pilihan kunci jarak jauh. Sementara itu, batasan estimasi nilai data sebagaimana diindikasikan oleh Agus Mulyanto (2016) diselesaikan dari dua hal mendasar, yaitu keuntungan dan biaya. Sebuah data bisa dianggap penting jika keuntungannya lebih besar daripada biaya besar untuk mendapatkan data. Juga dapat dikatakan bahwa estimasi nilai data akan lebih sesuai jika menggunakan penelitian cost-viability atau money saving benefit.

\section{Peran Sistem Informasi Manajemen berbasis komputer dalam pengambilan keputusan}

Insentif untuk data diidentifikasi dengan sebuah pilihan, yaitu tempat di mana Kerangka Data Administrasi dukungan untuk seorang pemimpin dalam suatu asosiasi dapat digambarkan dalam tiga fase, interaksi antara lain, mendapatkan, merencanakan, dan memilih. Papan Data Framework Backing biasanya mencakup banyak penanganan, catatan PC dan non-PC. Pada poin utama, untuk lebih spesifiknya, fase pemahaman hubungannya dengan Kerangka Data Administrasi adalah siklus pemeriksaan yang menggabungkan pemeriksaan informasi dengan hati-hati atau dengan cara yang telah ditentukan sebelumnya dan selanjutnya dengan cara yang luar biasa. Kerangka data harus menganalisis semua informasi dan menyajikan permintaan untuk pengujian tambahan. Baik SIM dan asosiasi harus memberikan saluran korespondensi untuk masalah yang jelas berbeda untuk disampaikan kepada asosiasi tingkat tinggi sehingga mereka dapat ditangani. Pada tahap ini, penting untuk mengkarakterisasi beberapa prospek. Dukungan Kerangka Data eksekutif memerlukan kumpulan data yang terkait dengan publik, pesaing dan informasi internal selain strategi untuk mengikuti dan menemukan beberapa masalah.

Pada tahap berikutnya, khususnya rencana, yang sebanding dengan Kerangka Data Administrasi adalah menetapkan beberapa model pilihan yang akan disiapkan tergantung pada informasi yang ada dan memberikan rencana terobosan untuk menangani masalah sekali lagi. Model-model yang ada harus membantu dengan memecah metode elektif ini. Para eksekutif Data Framework Backing terdiri dari pemrograman terukur seperti pemrograman demonstrasi lainnya. Ini termasuk metodologi yang lebih terorganisir, mengendalikan model, dan pemulihan kumpulan data. Pada fase 
pilihan ini, ini seharusnya menjadi yang terbaik saat hasil rencana diperkenalkan sebagai pilihan. Jika perlombaan politik telah dibuat, tugas Kerangka Data Administrasi akan diisi sebagai bermacam-macam informasi untuk kritik. Bantuan SIM pada tahap penentuan adalah untuk memilih jenis model yang berbeda. Ketika pilihan telah dibuat, bagian dari SIM berubah menjadi bermacam-macam informasi untuk masukan dan evaluasi nanti. Bantuan MIS pada tahap pilihan adalah untuk memilih model pilihan yang berbeda untuk memimpin investigasi keterkaitan (pemeriksaan keterpengaruh) dan memutuskan metode penentuan. Dukungan SIM untuk dinamika terdiri dari kumpulan data total, kemampuan pemulihan basis informasi, pemrograman logis terukur dan lainnya, dan basis model yang menggabungkan pemrograman peragaan pilihan. Ini menyiratkan bahwa jika tidak ada keputusan atau pilihan, data akan hilang. Pilihan bisa berubah dari pilihan iteratif langsung ke pilihan kunci jarak jauh. Kemudian menurut Agus Mulyanto (2016zl), batasan untuk mengkuantifikasi nilai data diselesaikan dari dua hal prinsip, yaitu keuntungan dan biaya. Sebuah data dianggap penting jika keuntungannya lebih menarik daripada biaya untuk mendapatkannya dan sebagian besar data tidak dapat dinilai secara tepat. Manfaat dengan unit bernilai signifikan untuk uang tunai, namun nilai kecukupannya dapat dievaluasi. Demikian juga dapat dikatakan bahwa estimasi nilai data akan lebih tepat jika menggunakan cost viability atau investigasi keuntungan penghematan uang.

\section{Peranan SIM dalam Pengambilan Keputusan}

Mungkin kemampuan utama dalam administrasi, khususnya dinamika, seorang pelopor lebih sering daripada tidak, pertimbangan dan renungannya digunakan untuk merenungkan siklus dinamis. Semakin tinggi situasi seseorang dalam inisiatif otoritatif, dinamika berubah menjadi tugas utama yang harus diselesaikan. Tingkah laku dan metode perintis dalam teladan dinamis sangat memengaruhi tingkah laku dan mentalitas staf mereka. Dinamika adalah konsekuensi dari pemikiran kritis, tanggapan terhadap suatu penyelidikan sebagai hukum keadaan, dan merupakan pilihan salah satu opsi dari opsi lain saat ini, sama seperti penyelesaian perspektif tentang masalah atau masalah terdekat. Konsekuensi dari dinamika adalah pilihan. Dinamis memiliki dua kapasitas, khususnya: tahap awal dari semua latihan manusia yang sadar dan terkoordinasi, baik secara eksklusif dan dalam pertemuan, baik secara kelembagaan dan hierarki, dan sesuatu yang canggih, menyiratkan bahwa ia mengidentifikasi dengan diidentifikasi dengan masa depan, masa depan ( dampak atau dampaknya bertahan lama sekali). Motivasi di balik dinamika, khususnya: tujuan tunggal, terjadi ketika pilihan berikutnya hanya menyangkut satu masalah. Artinya, setiap kali disimpulkan tidak akan ada hubungan dengan masalah yang berbeda, dan alasan ganda terjadi ketika pilihan berikutnya mencakup lebih dari satu masalah, yang menyiratkan bahwa pilihan diambil untuk sementara waktu untuk menangani setidaknya dua masalah, yang berlawanan. Atau tidak bertentangan. Seperti yang diindikasikan oleh Syamsi (1995: 13) komponen dalam dinamika yang harus diperhatikan adalah: (1) alasan dinamika, untuk lebih spesifik mengetahui terlebih dahulu target yang akan dicapai dari yang dinamis, (2) membedakan pilihan elektif dengan mengatasi masalah tersebut. Dipilih untuk mencapai tujuan ini. Oleh 
karena itu, penting untuk membuat ikhtisar tentang jenis kegiatan yang memungkinkan diadakannya perlombaan, (3) perkiraan mengenai faktor-faktor yang tidak dapat diketahui sebelumnya atau melewati ruang lingkup orang (kejadian liar), (4) metode atau instrumen yang digunakan untuk menilai atau mengukur konsekuensi dinamika. Komponen dinamis yang dapat dimanfaatkan oleh inisiatif pada awalnya harus memiliki opsi untuk mengaudit dan mempertimbangkan motivasi di balik dinamika, masalah bukti yang dapat dikenali, variabel dalam dan luar yayasan / asosiasi, seperti metode untuk dinamika.

\section{Faktor-faktor yang Mempengaruhi Pengambilan Keputusan}

Dalam siklus dinamis, asosiasi tidak dapat diisolasi dari elemen yang memengaruhinya. Variabel-variabel tersebut meliputi:

a. Posisi atau posisi untuk menentukan pilihan, posisi atau posisi dapat ditemukan sejauh:

(a) Posisi, sebagai pemimpin, kepala, atau staf, (b) posisi kenaikan, sebagai esensial, strategi, administratif, hierarki, atau khusus.

b. Persoalan atau persoalan merupakan batas pencapaian tujuan, yang merupakan penyimpangan berdasarkan apa yang umumnya diantisipasi, diatur, diinginkan atau harus diselesaikan. Isu dibagi menjadi 2 macam, yaitu isu terorganisir yang spesifik dan isu yang tidak terstruktur.

c. Keadaan adalah setiap salah satu elemen dalam ekspresi uamh yang diidentifikasi satu sama lain, dan yang bersama-sama menyebarkan efeknya pada kita dan apa yang sedang kita coba lakukan.

d. Kondisi semuanya merupakan elemen yang bersama-sama menentukan kemajuan kita, kemampuan untuk melakukan atau kapasitas kita. Sebagian besar dari elemenelemen ini adalah aset.

e. Sasaran Destinasi yang akan dicapai, baik tujuan individu, tujuan unit (solidaritas), tujuan otoritatif, dan target bisnis secara keseluruhan telah dipastikan atau diputuskan. Sasaran yang telah diselesaikan secara dinamis sedang setengah jalan atau sasaran sasaran.

\section{Jenis-jenis Pengambilan Keputusan}

Jenis-jenis keputusan dapat disusun berdasarkan berbagai sudut pandang dan secara garis besar dikenal tiga jenis keputusan yaitu:

a. Keputusan berdasarkan tingkat keputusan Pada umumnya sebuah lembaga memiliki hierarki manajemen. Secara klasik hierarki ini terbagi atas 3 tingkatan yaitu: manajemen puncak, manajemen menengah dan manajemen tingkat bawah. B. Keputusan yang berdasarkan regularitas Keputusan yang dikemukakan oleh Simon (1995) dibagi menjadi 2 yaitu:

(1) Pengambilan keputusan terprogram : pengambilan keputusan yang bersifat rutinitas dan berulang-ulang dengan cara penannggulangan telah ditentukan untuk penyelesaikan masalah melalui: prosedur (serangkaian langkah yang berhubungan dan berurutan yang harus diikuti oleh pengambil keputusan), aturan (ketentuan yang mengatur yang harus dilakukan dan yang tidak 
boleh dilakukan oleh pengambil kebijakan), kebijakan (pedoman yang menentukan parameter untuk membuat keputusan),

(2) Pengambilan keputusan tidak terprogram: pengambilan keputusan yang bersifat tidak rutinitas dan digunakan untuk menyelesaikan masalah yang tidak berstuktur.

b. Keputusan berdasarkan lingkungan : keputusan ini dibedakan menjadi 4 kelompok yaitu:

\section{(1) Pengambilan keputusan dalam kondisi pasti, (2) pengambilan keputusan dalam kondisi beresiko, (3) pengambilan keputusan dalam kondisi tidak pasti, (4) pengambilan keputusan dalam kondisi konflik.}

\section{PENUTUP}

Inovasi data merupakan inovasi yang dimanfaatkan untuk memperoleh data baik di dalam maupun dari jauh karena perkembangan globalisasi. Asosiasi adalah kerangka kerja terbuka dengan tujuan agar kemajuan peningkatan ini tanpa syarat akan menjadi asosiasi. Penggunaan inovasi dalam pergaulan harus diubah sesuai dengan atribut pergaulan yang sebenarnya agar tidak terjadi perselisihan. Dengan adanya inovasi data dapat memberikan pekerjaan yang besar baik dalam kemampuan kerja maupun budaya kerja antar individu, antar unit, maupun naluri umum yang ada dalam pergaulan sehingga inovasi dan pergaulan memiliki keterkaitan dan dampak satu sama lain. Mengingat penggambaran yang telah diklarifikasi di atas, sangat terbukti bahwa kehadiran inovasi PC telah membuat komitmen positif terhadap kerangka data administrasi dan MIS juga sangat dibutuhkan oleh para pionir dalam sebuah asosiasi atau organisasi untuk dinamika yang dapat diandalkan. Semakin rumit latihan dan peningkatan unit / unit / divisi dalam suatu asosiasi maka semakin merepotkan koordinasi dan korespondensi jika tidak dibuat kerangka kerja.

Mengingat penggambaran yang telah diklarifikasi di atas, terbukti bahwa kehadiran inovasi PC telah membuat komitmen positif terhadap kerangka data dewan dan SIM juga sangat dibutuhkan oleh para pionir dalam sebuah asosiasi atau organisasi untuk dinamika yang penuh perhatian. Bagi supervisor, kehadiran PC dalam SIM tidak hanya memberikan kontribusi nyata, bahkan interaksi dinamis menjadi lebih sederhana, lebih murah, dan dapat didukung. Mengenai penggambaran di atas, beberapa ujung dapat ditarik:

1. SIM bukanlah PC, ini merupakan peningkatan dari ilmu eksekutif dan telah ada beberapa waktu sebelum munculnya PC; 
2. SIM adalah teknik pelopor / pimpinan organisasi dalam menetapkan pilihan yang bertanggung jawab;

3. Kehadiran inovasi PC telah membawa perubahan signifikan pada latihan The Board Data Frameworks; 4. SIM berbasis PC dapat memberikan data yang bermutu, penting dan bermutu (sebagai material secara dinamis), khususnya data yang berkaitan dengan organisasi / asosiasi, yaitu data yang tepat dan jelas layak atau tidak lama atau usang;

4. Dengan hadirnya SIM berbasis PC, maka kapasitas file atau laporan yang dilakukan oleh direksi diotomatiskan dengan lebih lincah dan mahir dibandingkan sebelum menggunakan penimbunan secara manual.

5. Dengan SIM berbasis PC, penimbunan otomatis ini dapat ditangani dengan cepat dan pemburuannya tidak memakan waktu cukup lama, selain itu pencatatan dapat ditangani dengan cermat. Dengan aksi SIM berbasis PC ini, pelopor / direktur organisasi dapat lebih sederhana, lebih murah, produktif dan sukses dalam usahausaha yang dinamis, mengingat untuk melengkapi kapasitas administrasi, seperti mengatur, menyusun, memindahkan (mengaktifkan), dan (mengendalikan) akibat-akibat yang ditimbulkannya. Harus diwakili

\section{Kesimpulan}

Manajemen seringkaliidiharapkan dengan berbagai macam persoalan berkaitandengan jenisbisnis dan usaha yang dijalaninya. Persoalan-persoalan yang dihadapi olehmanajemen sangatlah bertautan. Baik masalah yang sifatnya rutintas atau yang besifat khusus.Manajer yang baik, adalah manajer yang dapat mengambil keputusan yang tepatdisaat yang tepat pula. Walaupun diketahui bahwa setiap keputusan yang diambil akanberdampak besar bagi kehidupan perusahaan dan lingkungan sekitar. Tetapi hanyakeputusanyang tepat yang dapat menjadikan perusahaan atau suatu entitas bisnis dapatbertahan.Seiiring berkembangnya pesat teknologi, telah muncul adanya suatu system yangdigunakan untuk membantu manajer untuk mengambil keputusan yang tepat dan cepat,cepat diartikan sebagai cepat dalam melakukan analisis berbagai macam alternativepilihan, serta pengakhiran dari proses pemikiran tentang masalahyang dihadapi

\section{DAPUS(DAFTAR PUSTAKA)}

Sri Dewi Anggadini.2013 “Analisis Sistem Informasi Manajemen Berbasis Komputer Dalam Proses Pengambilan Keputusan" Majalah Ilmiah UNIKOM Vol.11 No. 2

Lipursari Anastasia. 2013 "Peran Sistem Informasi Manajemen (Sim) 
Dalam Pengambilan

Keputusan" JURNAL STIE

SEMARANG, VOL 5, NO 1, Edisi

Februari 2013 (ISSN : 2252-7826)

Paul, Lorina "Analisis Sistem Informasi Manajemen Berbasis Komputer

Dalam Proses Pengambilan

Keputusan" Jurnal TeIKa, Volume

8, Nomor 2, Oktober 2018

Sutiyadi "ANALISIS PENGARUH SISTEM INFORMASI MANAJEMEN BERBASIS KOMPUTER, PELATIHAN DAN DISIPLIN KERJA TERHADAP KINERJA PEGAWAI PADA KANTOR PEMERINTAHAN PROVINSI DKI JAKARTA" Jurnal Riset Manajemen dan Bisnis Vol.2, No.1, Februari 2017 : 53 - 62 ISSN 2527- 7502

Kasmiah Ali "PENGAMBILAN KEPUTUSAN BERBASIS KOMPUTER DALAM PERSPEKTIF SISTEM INFORMASI MANAJEMEN" Meraja Journal Vol. 1, No. 3, November 2018

http://s3.amazonaws.com/ppt-download/ peran-sistem-informasi-manajemendalampengambilan-keputusanorganisasi1234846692787089-2.doc

http://katalog.library.perbanas.ac.id/ download_3922_Rangkuman.pdf http://yudiachmadriski.blogspot.com/ 2012/10/analisis-peranansisteminformasi.html

http://www.slideshare.net/bang_qq/peran sistem-informasi-manajemendalampengambilan-keputusan-organisasi

http://www.scribd.com/doc/8336496/ Analisis-Peranan-SistemInformasiManajemen-Berbasis-KomputerDalamProses-Pengambilan 